\title{
Karakterisasi dan Uji Aktivitas Antioksidan serta Penetapan Kadar Fenolik Total Ekstrak Etanol Kulit Batang Kapuk Randu (Ceiba petandra L. Gaertn)
}

\author{
Yamin*, Rini Hamsidi, Nasria, Sabarudin
}

Fakultas Farmasi Universitas Halu Oleo, Kampus Hijau Bumi Tridharma, Jl. H. E. A. Mokodompit Kendari 93232

E-mail: yamin_taeri1975@yahoo.com

\begin{abstract}
Abstrak
Antioksidan merupakan senyawa penting dalam menjaga kesehatan tubuh karena berfungsi sebagai penangkap radikal bebas dalam tubuh. Radikal bebas dapat menginduksi penyakit kanker, aterosklerosis, dan penuaan dini. Penelitian ini bertujuan untuk mengkarakterisasi ekstrak, serta menguji potensi antioksidan dan menentukan kadar fenolik total ekstrak etanol kulit batang kapuk randu (Ceiba petandra L Graetn). Aktivitas antioksida ditentukan dengan uji penangkal radikal bebas DPPH (2,2-diphenyl-1pikrilhidrazil). Kandungan fenolik total ditentukan dengan metode Folin-Ciocalteau menggunakan spektrofotometri UV-Vis. Hasilnya menunjukkan bahwa ekstrak etanol kulit batang $C$. petandra L Graetn mengandung metabolit sekunder yang terdiri dari alkaloid, flavonoid, fenol tannin dan saponin, memiliki potensi antioksidan yang kuat dengan nilai $\mathrm{IC}_{50}$ sebesar $26,06 \mu \mathrm{g} / \mathrm{mL}$, serta memiliki kadar fenolik total sebesar 43,063 $\mu \mathrm{g} / \mathrm{mL}$
\end{abstract}

Kata kunci: Antioksidan, kulit batang Kapuk Randu, DPPH

\section{Pendahuluan}

Indonesia yang merupakan negara berkembang mempunyai keterbatasan dalam penanggulangan masalah kesehatan, yaitu prevalensi penyakit degeneratif makin meningkat [1]. Selain akibat penyakit degeneratif, penuaan pun juga menjadi masalah kesehatan di Indonesia. Indonesia seperti negara-negara lainnya dikawasan Asia Pasifik akan mengalami penuaan penduduk dengan cepat. Penuaan ditandai dengan hilangnyaintegritas fisiologis yang progresif, yangmemicu gangguan fungsi dan meningkatkanrisiko kematian. Kemunduran fungsi inimenjadi faktor risiko utama patologipada manusia meliputi kanker, diabetes,kelainan kardiovaskuler, dan penyakitneurodegeneratif [2].

Semua penyakit tersebut ialah akibat dari radikal bebas yang terpapar pada tubuh manusia, sehingga radikal bebas masih menjadi penyebab kematian di Indonesia. Radikal bebas tersebut bersifat reaktif dalam mencari pasangan elektronnya, jika sudah terbentuk dalam tubuh maka akan terjadi reaksi berantai menghasilkan radikal bebas yang baru yang akhirnya jumlah radikal bebas ini akan terus bertambah. Keadaan dimana tubuh terpapar radikal bebas dalam jumlah yang melebihi kapasitas tubuh disebut stress oksidatif. Oleh karena itu tubuh kita memerlukan substansi penting yaitu antioksidan yang dapat membantu melindungi tubuh dari serangan radikal bebas dengan meredam efek negatif yang disebabkan oleh senyawa ini.

Antioksidan merupakan senyawa penting dalam menjaga kesehatan tubuh karena berfungsi sebagai penangkap radikal bebas dalam tubuh. Radikal bebas dapat menginduksi penyakit kanker, aterosklerosis, dan penuaan dini [3]. Pada umumnya, antioksidan dibagi menjadi dua jenis yaitu antioksidan sintetik dan antioksidan alami. Antioksidan sintetis yang banyak digunakan berbahaya bagi kesehatan karena bersifat racun jika dikonsumsi dengan konsentrasi yang berlebih. Oleh karena itu, diperlukan antioksidan alami yang cenderung tidak memiliki efek samping dan bermanfaat bagi kesehatan [4].

Senyawa antioksidan alami tumbuhan adalah senyawa fenolik atau polifenolik yang dapat berupa golongan flavonoid, tokoferol dan asam-asam polifungsional. Salah satu tanaman yang memiliki potensi antioksidan adalah kapuk randu (Ceiba petandra L. Gaertn), dimana fraksi metanol kulit batang kapuk randu sedniri memiliki kadar fenolik total yang lebih besar dibandingkan dengan fraksi n-heksana dan etil asetat yakni sebesar 90,87 $\mu \mathrm{gGAE} / \mathrm{mL}$, sehingga penelitian ini akan dilakukan karakterisasi ekstrak etanol dari kulit batang kapuk randu serta uji aktivitas antioksidan dengan menggunakan metode DPPH dan kadar total fenoliknya.

\section{Metode}

2.1 Preparasi

Daun kapuk randu diperoleh dari Kelurahan Bonggoeya Kecamatan Wua-Wua Kota Kendari Provinsi Sulawesi Tenggara. Sebanyak 950 gram serbuk simplisia 
Kulit batang kapuk randu (C. petandra (L.) Gaertn) diekstrkasi dengan etanol 96\% selama 3 x 24 jam, dimana setiap 1 x 24 jam dilakukan penyaringan, yang selanjutnya dilakukan pemekatan dengan menggunakan Rotary evaporator. Selanjutnya ekstrak yang diperoleh digabungkan dan ditimbang beratnya untuk ditentukan besar rendemennya.

\subsection{Penapisan Fitokimia}

Penapisan fitokimia secara kualitatif dilakukan dengan dua metode, yaitu metode reaksi warna/ pengendapan dan metode kromatografi lapis tipis (KLT) [5].

\subsection{Karakteristik Ekstrak}

Karakteristik yang diperiksa meliputi parameter spesifik yaitu organoleptik yang mendeskripsikan bentuk, warna, bau dan rasa, serta parameter non spesifik (kadar air dan kadar abu) [6].

\subsection{Pengujian Aktivitas Antioksidan}

Ekstrak etanol kulit batang kapuk randu dilakukan dengan menggunakan metode DPPH (2,2-difenil-1pikrilhidrazil) secara spektrofotometri UV-Visibel [7]

\section{Pembuatan Larutan DPPH}

Pereaksi DPPH konsentrasi 50 ppm dibuat dengan cara DPPH ditimbang sebanyak 5 mg kemudian dilarutkan dengan pelarut etanol $96 \%$ hingga semua larut, kemudian dimasukkan ke dalam labu takar $100 \mathrm{~mL}$ dan diencerkan hingga tanda tera kemudian dihomogenkan [8].

\section{Penentuan Panjang Gelombang Maksimum DPPH}

Penentuan panjang gelombang maksimum larutan DPPH dilakukan dengan memipet 3,5 ml larutan DPPH 50 ppm ditambahkan dengan 0,5 ml etanol 96\% dan dikocok hingga homogen, diinkubasi selama 30 menit pada suhu ruang yang gelap kemudian diamati serapannya pada rentang panjang gelombang 400-800 nm menggunakan spektrofotometer UV-Vis [8].

Pengukuran serapan sampel dengan menggunakan spektrofotometer $U V$-Vis

Pengujian aktivitas antioksidan dilakukan dengan uji DPPH terhadap ekstrak etanol kulit batang kapuk randu $C$. petandra dilakukan dengan mengambil $0,5 \mathrm{~mL}$ larutan sampel dari berbagai konsentrasi, kemudian ditambahkan 3,5 mL DPPH lalu diinkubasi pada ruangan gelap, dan diukur serapannya pada panjang gelombang maksimum.

\section{Pengujian Larutan Vitamin C sebagai pembanding}

Asam askorbat ditimbang $10 \mathrm{mg}$ kemudian dilarutkan dalam etanol $96 \%$ hingga larut selanjutnya dimasukkan kedalam labu takar $100 \mathrm{ml}$ dan diencerkan hingga tanda tera sehingga diperoleh konsentrasi 100 ppm. Dilakukan pengenceran untuk membuat seri konsentrasi 1 ppm, 2 ppm, 3 ppm, 4 ppm dan 5 ppm. Setelah itu 0,5 ml larutan masing-masing konsentrasi dimasukkan ke dalam tabung reaksi dan ditambahkan 3,5 ml larutan DPPH 50 ppm dikocok hingga homogen dan diinkubasi pada suhu ruang selama 30 menit. Serapan diukur menggunakan spektrofotometri Uv-Vis pada panjang gelombang maksimum DPPH.

\section{Hasil dan Pembahasan}

Sampel Kulit batang kapuk randu diperoleh dari Kelurahan Bonggoeya Kecamatan Wua-Wua kota Kendari, dimana sampel kulit batang kapuk randu tersebut di panen pada sore hari. Pengambilan ini dilakukan agar metabolit sekunder yang diperoleh maksimal. Sampel kulit batang kapuk tersebut selanjutnya dikeringkan di bawah sinar matahari yang ditutupikain hitam. Hal ini dilakukan agar tidak terjadi paparan langsung sinar matahari. Dimana jika terjadi paparan langsug dengan sinar matahari akan terjadi degradasi dari metabolit yang ada dalam simplisia tersebut.

Metode ekstraksi yang digunakan adalah metode maserasi. Pemilihan metode ini dikarenakan metodenya sederhana dan tidak menjenuhkan. Disamping itu metabolit yang tidak tahan panas tidak mengalami kerusakan atau hilang selama proses ekstraksi. Maserat ditarik dengan menggunakn pompa vakum pada suhu $40{ }^{\circ} \mathrm{C}$ sehingga diperoleh ekstrak etanol sebesar 39,80 gram dan nilai rendamennya sebesar $4,18 \%$.

Pengujian fitokimia dilakukan untuk mengetahui kondungan metobolit sekunder yang ada dalam sampel. Hasil uji fitokimi didapatkan bahwa dalam ekstrak etanol daun kapuk randu terdapat alkaloid, flavonoid, fenol, tannin, dan saponin (Tabel 1).

Tabel 1. Hasil uji fitokimia ekstrak Kulit batang kapuk randu ( $C$. petandra L. Gaertn)

\begin{tabular}{cllcc}
\hline No. & $\begin{array}{l}\text { Metabolit } \\
\text { Sekunder }\end{array}$ & Pereaksi & Hasil & $\begin{array}{c}\text { Standar } \\
\text { (warna) }\end{array}$ \\
\hline 1. & Alkaloid & Dragendorff & + & $\begin{array}{c}\text { endapan } \\
\text { coklat } \\
\text { mudah }\end{array}$ \\
\hline 2. & Flavonoid & $\begin{array}{l}\text { Serbuk Mg }+ \\
\text { HCl pekat }\end{array}$ & + & $\begin{array}{c}\text { Merah } \\
\text { jingga }\end{array}$ \\
\hline 3 & Fenolik & Besi klorida & + & $\begin{array}{c}\text { Hijau } \\
\text { kecoklatan }\end{array}$ \\
\hline 4. & Saponin & Akuades & + & $\begin{array}{c}\text { Terbentuk } \\
\text { busa stabil }\end{array}$ \\
\hline 5. & Tanin & FeCl3 1\% & + & $\begin{array}{c}\text { Hijau } \\
\text { kehitaman }\end{array}$ \\
\hline
\end{tabular}

Kualitas ekstrak etanol kulit batang dan daun kapuk randu dapat terjamin dengan memenuhi suatu standar mutu ekstrak. Selain itu, karakteristik ekstrak perlu dilakukan agar dapat diperoleh bahan baku yang seragam sehingga dapat menjamin efek farmakologi tanaman tersebut. Karakterisasi ekstrak kulit batang dan daun kapuk randu meliputi parameter spesifik yaitu identitas, organoleptik, kadar sari larut air, dan kadar sari larut etanol. 
mendekati 1 ( R2 = 1 atau mendekati 1). Berdasarkan persamaan regresi linier tersebut, serta hasil pengukuran absorbansi ekstrak etanol kulit batang kapuk randu sebesar 0,595 , maka kadar total fenolik yang yang terdapat dalam ekstrak etanol kulit batang kapuk randu sebesar 43,063 $\mu \mathrm{g} / \mathrm{mL}$.

\section{Kesimpulan}

Ekstrak kulit batang kapuk randu memiliki metabolit sekunder yang terdiri dari flavonoid, alkaloid, fenolik, saponin dan tannin, dengan kadar fenolik total sebesar 43,063 $\mu \mathrm{g} / \mathrm{mL}$, serta menunjukkan aktivitas antioksidan yang tergolong kuat dengan nilai $\mathrm{IC}_{50}$ sebesar $26.06 \mu \mathrm{g} / \mathrm{mL}$.

\section{Ucapan Terima Kasih}

Ucapan terima kasih diberikan kepada LPPM UHO dan Fakultas Farmasi yang telah memfasilitasi terlaksananya penelitian ini.

\section{Daftar Pustaka}

1. Werdhasari A. Peran Antioksidan Bagi Kesehatan. Jurnal Biomedik Medisiana Indonesia, 2014, 3(2);59-68
2. Lopez-Otin C, Blasco MA, Partridge L, Manuel S, Guido K The Hallmarks of Aging. Cell, 2013,153(6);194-217. doi:10.1016/j.cell.2013.05.039

3. Hernarni dan Rahardjo. Tanaman Berkhasiat Antioksidan. Jakarta: Penebar Swadaya, 2005.

4. Sarastani D, Soekarto ST, Muchtadi TR, Fardiaz D, Apriyantono A. Aktivitas Antioksidan Ekstrak danFraksi Ekstrak Biji Atung, Jurnal Teknologi dan Industri Pangan, 2002, 13 (2).

5. Farnsworth NR. Biological and phytochemical Screening of Plants. J Pharm Sci, 1966, 55(3);225-76.

6. Depkes RI, 2000, Inventaris Tanaman Obat Indonesia Jilid I. Jakarta: Departemen Kesehatan dan Kesejahteraan Republik Indonesia, 2000.

7. Zou Y, Lu Y, Wei D. antioxidant activity of flavonoid rich extract of Hypericum perforatum L. In Vitro. Journal Agric Food Chem, 2004, 52;5032-9.

8. Brand-Williams W, Cuvelier ME. Use of a free radical method to evaluate antioxidant activity. Food Sci Tech, 1995, 28(1);25-30. doi.org/10.1016/S0023-6438(95)80008-5.

9. Khadijah, 2017, Penentuan Total Fenolik dan Aktivitas Antioksidan Ekstrak Etanolik Daunsamama (Anthocephalus macrophylus) Asal Ternate, Maluku Utara. 